\title{
Imagen y conocimiento: Retos epistemológicos de la sociología visual.
}

\author{
Images and knowledge: Epistemological challenges of \\ visual sociology.
}

Eduardo Bericat Alastuey

Universidad de Sevilla (ESPAÑA)

ebericat@us.es

Recibido: 13.05 .2010

Aceptado: 18.01 .2011

\section{RESUMEN}

El contraste existente entre un mundo social plagado de imágenes y una sociología todavía ciega a cualquier tipo de representación visual constituye una flagrante contradicción. Elaboramos una sociología ciega cuando en nuestros estudios omitimos tanto la construcción visual de lo social como la construcción social de lo visual. También elaboramos una sociología ciega cuando prescindimos de la imagen como medio o instrumento de investigación. En efecto, la mayoría de los sociólogos no considera que las imágenes, al igual que las palabras o los números, constituyan un modo de representación del mundo capaz de ser incorporado a los procesos mediante los que la ciencia social produce conocimiento. En este sentido, el presente artículo trata de establecer algunas bases desde las que abordar una reflexión epistemológica en torno a la idea de que las imágenes puedan, y en su caso deban, incorporarse a los procesos de investigación que habitualmente desarrollan las ciencias sociales. Analizando la teoría visual del significado de Ludwig Wittgenstein, así como la teoría de la coherencia de las imágenes de John Berger, se muestra que las imágenes pueden y deben ser incorporadas a los procesos de producción de conocimiento haciendo adecuado uso de su naturaleza dual. Se concluye que las imágenes fotográficas pueden ser incorporadas a la investigación, bien en tanto índices, operando con las conexiones existenciales establecidas entre los elementos de la imagen y los objetos de la realidad, o bien en tanto iconos, utilizando la homología existente entre la situación representada por la imagen y el hecho de la realidad. 


\title{
PALABRAS CLAVE
}

Sociología visual; metodología; epistemología; investigación social; fotografía; imágenes; conocimiento; índices; iconos; modos de representación; modos de comunicación.

\begin{abstract}
Nowadays a clear contradiction exists between a social world in which images are everywhere and a sociology that scarcely considers any kind of visual representations. This «blind sociology» takes into account neither the visual construction of the social, nor the social construction of the visual. In addition, this «blind sociology» does not use image to carry out social research. Most sociologists think that words and numbers are appropriate modes of representation to produce social knowledge but that images are not. This article is an epistemological reflection on the possibility and necessity of incorporating images into the processes by which the social sciences produce knowledge. Ludwig Wittgenstein's Picture Theory of Meaning and John Berger's theory about the coherence of the images show that images not only can, but also must be incorporated into the processes of knowledge production. The dual nature of photographic images permits us to use them in two different ways. Photographic images can be incorporated into social research as indexes, given the existential or empirical connections that link the different parts of the image with real objects. But we can also incorporate photographs as icons, given the homology between the situation represented by the image and real facts.
\end{abstract}

\section{KEY WORDS}

Visual sociology; methodology; epistemology; social research; photography; images; knowledge; index; icon; modes of representation; modes of communication.

\section{INTRODUCCIÓN}

El motivo intelectual que subyace al presente artículo no es otro que la contradicción existente entre, por una parte, un mundo social plagado de imágenes y, por otra, una sociología que apenas utiliza aún en sus análisis la representación visual.

La abrumadora presencia de imágenes en el actual universo perceptivo y comunicativo de los seres humanos es tan evidente que apenas reclama demostración alguna. Además, como bien señala Nicholas Mirzoeff, no importa tanto el

EMPIRIA. Revista de Metodología de Ciencias Sociales. N. . 22, julio-diciembre, 2011, pp. 113-140. ISSN: $1139-5737$ 
hecho de que consumamos gran cantidad de imágenes, cuanto el hecho de que se haya impuesto una propensión a visualizar todo tipo de realidad (Mirzoeff, 1998). Es obvio que en el siglo XXI la imagen está adquiriendo un protagonismo especial, como así lo prueba el complejo universo de pantallas en el que viven hoy los seres humanos. Pantallas de papel, de cine, de televisión, de ordenador, de teléfonos móviles o de consolas electrónicas que proyectan sobre las retinas un continuo flujo de imágenes. En suma, todo apunta a un nuevo posicionamiento, quizás hegemónico, de las imágenes en el marco de nuestros modos básicos de representación y de comunicación. La cultura visual constituye ya hoy un elemento clave del mundo social y personal en el que se desenvuelve la vida de los seres humanos.

Dada la relevancia vital que están adquiriendo las imágenes, deberíamos preguntarnos, con Mitchell, qué significa para las formaciones sociales el hecho de que los seres humanos sean seres visuales (Mitchell, 2005:244). Las personas tienen ojos con los que miran el mundo, y las ciencias sociales no pueden seguir ignorando lo que estas personas ven con sus ojos. Mitchell define la «cultura visual», en cuanto disciplina académica, como «el estudio de la construcción cultural de la experiencia visual en la vida cotidiana, así como también en los medios, en las representaciones y en las artes visuales ${ }^{1} \gg$ (Dikovitskaya, 2005:55). Desde una perspectiva sociológica, «la cultura visual es lo que hace posible una sociedad de personas con ojos» (Mitchell, 2005:245), lo que necesariamente nos llevaría a tener que estudiar tanto la construcción social de lo visual, como la construcción visual de lo social. En el primer caso aplicaríamos la perspectiva sociológica al estudio de las imágenes, mientras que en el segundo analizaríamos los componentes visuales de toda sociabilidad.

Ahora bien, el hecho de que la sociología, así como el resto de las ciencias sociales, asuma la realidad de este fabuloso universo de imágenes, cuestión que parece bastante obvia, no implica necesariamente que la imagen sea considerada como un modo de representación y de comunicación del mundo capaz de ser incorporado a los procesos mediante los que la ciencia produce conocimiento. Esto es, no es lo mismo creer que las imágenes deben constituir un objeto de estudio de las ciencias sociales, que pensar que las imágenes puedan ser un instrumento científico muy útil, en algunos casos imprescindible, a la hora de estudiar la realidad social. El presente artículo trata, precisamente, de establecer algunas bases con las que abordar una reflexión epistemológica en torno a la idea de que las imágenes puedan, y en su caso deban, incorporarse a los procesos de investigación que habitualmente desarrollan las ciencias sociales.

En el momento actual de las ciencias sociales es muy necesario ser conscientes tanto de la necesidad de incorporar las imágenes como de la dificultad que comporta tal incorporación. En este sentido, puede afirmarse que el princi-

\footnotetext{
${ }^{1}$ En esta definición los términos «cultural» y «social» serían perfectamente intercambiables, ya que si bien el autor distingue entre cultura (estructura de símbolos) y sociedad (estructura de relaciones), entiende que ambas realidades son interdependientes.
}

EMPIRIA. Revista de Metodología de Ciencias Sociales. N. ${ }^{\circ}$ 22, julio-diciembre, 2011, pp. 113-140. ISSN: $1139-5737$ 
pal obstáculo con el que se encuentran las imágenes a la hora de ser utilizadas como herramienta de investigación tiene una naturaleza semiótica. Consiste en su probada incapacidad para constituir una estructura convencional de significación, esto es, un lenguaje, mediante el que establecer sentencias con un significado suficientemente preciso. Utilizando la clasificación de signos establecida por Charles S. Peirce (Peirce, 1931-58), este problema capital se expresaría señalando que las imágenes no constituyen símbolos, es decir, signos cuyo modo de representación es convencional y cuyo significado queda establecido mediante la aplicación de un cuerpo de normas convencionales. Según Peirce, tanto la conceptualización como el pensamiento sólo pueden realizarse mediante el concurso de una determinada estructura de símbolos.

Ahora bien, pese a la dificultad de establecer una gramática de las imágenes, o sistemas icónicos capaces de portar significados definidos, en este artículo se explora la posibilidad de que las imágenes puedan ser incorporadas a los procesos de producción de conocimiento merced a su doble naturaleza de índex y de icono. En el caso de las imágenes fotográficas que, en el exclusivo marco de este trabajo epistemológico ${ }^{2}$, utilizamos como punto de partida singular desde el que pensar todo tipo de imágenes, resulta muy evidente su carácter dual. Para Peirce la naturaleza representativa de un icono se basa en la semejanza entre el signo y el objeto, similitud que es evidente en el caso de las fotografías. Asimismo, la naturaleza representativa del índex se basa en la existencia de una conexión existencial directa entre el objeto y el signo, conexión física que en las fotografías viene establecida por la marca que imprime la luz que refleja el objeto sobre una determinada superficie.

Esta solución alternativa, que señala el camino de una posible incorporación dual de las imágenes a los procesos de producción de conocimiento científico, esto es, una incorporación en tanto índex y en tanto icono, ha de quedar enmarcada en el contexto de una renovada reflexión general acerca de los tres modos básicos de representación y de comunicación que siempre han utilizado las ciencias para representar el mundo. El mundo ha sido desde siempre representado mediante números, mediante palabras y mediante imágenes, lo que nos lleva a reflexionar sobre la naturaleza de cada uno de estos tres modos de representación, el matemático, el lingüístico y el icónico. Así pues, la perspectiva adecuada para reflexionar cabalmente sobre esta incorporación debe considerar la imagen en tanto uno de los tres modos básicos mediante los que los seres humanos nos representamos el mundo. Esto es, sus posibilidades de incorporación deberán ser concebidas en el marco de las múltiples interafectaciones que se dan entre estos tres modos. Dicho de otra forma, solamente desde la perspectiva de

\footnotetext{
${ }^{2} \mathrm{El}$ hecho de que esta reflexión epistemológica centre su atención exclusivamente en la imagen fotográfica, caracterizada por ser una representación visual «fija» y «muda», en absoluto significa que los productos audiovisuales deban quedar al margen de la investigación social. Antes al contrario, la combinación de sonidos e imágenes en movimiento no hace sino incrementar exponencialmente su utilidad para generar conocimiento social, como queda patente, por ejemplo, en la etnometodología audiovisual o en el videoanálisis sociológico.
}

EMPIRIA. Revista de Metodología de Ciencias Sociales. N. . 22, julio-diciembre, 2011, pp. 113-140. ISSN: $1139-5737$ 
una renovada ciencia multimodal podría en su caso resolverse el problema de la incorporación de las imágenes a la ciencia. Una ciencia elaborada, no con números, palabras o imágenes, sino una ciencia multimodal elaborada con números, con palabras y con imágenes.

Con esta perspectiva multimodal en mente, el artículo despliega un conjunto de argumentos epistemológicos amparados en las teorías elaboradas por dos pensadores, un filósofo y un humanista. En primer lugar, se expone la teoría visual del significado de Ludwig Wittgenstein, tal y como quedó perfilada en el Tractatus Logico-Philosophicus. Aunque tal teoría pretendía sentar unas bases precisas para establecer el significado de una proposición lingüística, la analogía visual de la que parte nos ilustra acerca de la lógica de representación que caracteriza a las imágenes. En segundo lugar, se expone la teoría de la coherencia de las imágenes de John Berger, propuesta teórica que fue concebida para contestar a la pregunta de si con una o con un conjunto de fotografías se podría transmitir una idea o se podría contar una historia, es decir, si era posible superar la inmanente ambiguiedad que caracteriza a toda fotografía y, por ende, a todo tipo de imagen.

\section{LAS IMÁGENES Y SU LÓGICA DE REPRESENTACIÓN: LA TEORÍA DEL SIGNIFICADO DE WITTGENSTEIN}

En el marco de este trabajo, el indudable valor de la teoría visual del significado de Wittgenstein deriva, no tanto de la posibilidad de aplicar la estructura de las imágenes a la determinación del sentido de las proposiciones lingüísticas, cuanto a la necesidad de comprender las relaciones epistémicas básicas implícitas en una imagen, relaciones que condicionan tanto la posibilidad como la naturaleza del conocimiento que podría emerger de su utilización científica. El establecimiento de estas relaciones epistémicas sirve para definir el estatuto de las imágenes en tanto un diferenciado modo de representación del mundo, y explica el hecho de que las imágenes puedan ofrecernos, no tan sólo formas alternativas de conocimiento, sino también formas alternativas de comunicación. Además, cualquier significado o sentido que contengan las imágenes deberá estará basado en esta estructura de relaciones epistémicas.

Con el objeto de ofrecer una síntesis de la teoría visual del significado de Wittgenstein, se han seleccionado un conjunto de sentencias publicadas en el Tractatus Logico-Philosophicus ${ }^{3}$. Este conjunto de sentencias se ha estructurado en cuatro grupos: en el primer grupo se ofrece un axioma fáctico; en el segundo queda bosquejada una lógica de la representación; en el tercero se conceptualiza la forma de figuración; y en el cuarto, y último, se introduce el concepto de figura

\footnotetext{
${ }^{3}$ Se ha respetado literalmente la traducción utilizada en la edición de Reguera y Muñoz (Reguera y Muñoz, 2000). Las notaciones numéricas incluidas en la tabla son las utilizadas en la versión original.
}

EMPIRIA. Revista de Metodología de Ciencias Sociales. N. ${ }^{\circ}$ 22, julio-diciembre, 2011, pp. 113-140. ISSN: $1139-5737$ 


\begin{tabular}{|c|c|}
\hline \multicolumn{2}{|r|}{ «Teoría Visual del Significado»-Wittgenstein } \\
\hline 1. & Nos hacemos figuras de los hechos \\
\hline 12. & La figura es un modelo de la realidad \\
\hline 2.141 . & La figura es un hecho \\
\hline 2.13 . & A los objetos corresponden en la figura los elementos de la misma \\
\hline 14.14. & $\begin{array}{l}\text { Las figura consiste en que sus elementos se interrelacionan de un modo y manera de- } \\
\text { terminada. }\end{array}$ \\
\hline 14.15 . & $\begin{array}{l}\text { Que los elementos de las figuras se comporten unos con otros de un modo y manera } \\
\text { determinados, representa que las cosas se comportan así unas con otras. } \\
\text { Esta interrelación de los elementos de la figura se llama su estructura y la posibilidad } \\
\text { de la misma, su forma de figuración. }\end{array}$ \\
\hline 14.16. & Para ser figura, pues, el hecho ha de tener algo en común con lo figurado. \\
\hline 14.17 & $\begin{array}{l}\text { Lo que la figura ha de tener en común con la realidad para poder figurarla a su modo y } \\
\text { manera -correcta o falsamente- es su forma de figuración. }\end{array}$ \\
\hline 14.18. & $\begin{array}{l}\text { Lo que cualquier figura, sea cual fuere su forma, ha de tener en común con la realidad } \\
\text { para poder siquiera -correctamente o falsamente- figurarla, es la forma lógica, esto es, } \\
\text { la forma de la realidad. }\end{array}$ \\
\hline 2.182 . & $\begin{array}{l}\text { Cualquier figura es también una figura lógica. (por el contrario, no toda figura es, pon- } \\
\text { gamos por caso, espacial). }\end{array}$ \\
\hline 2.202 . & La figura representa un posible estado de cosas en el espacio lógico. \\
\hline & \\
\hline 2.222 & Su verdad o falsedad consiste en el acuerdo o descuerdo de su sentido con la realidad \\
\hline
\end{tabular}

lógica. Creemos que de esta manera puede quedar claramente esbozado el modo en que las imágenes, y más especialemente las representaciones fotográficas, pueden ser legítimamente incorporadas al quehacer de las ciencias sociales.

\section{El axioma fáctico: visualizamos los hechos}

La sentencia con la que se inicia el apartado correspondiente a la teoría visual del significado es la [2.1], «Nos hacemos figuras de los hechos», que también podría traducirse por «Visualizamos los hechos» ${ }^{4}$. Esta sentencia anuncia la importancia de las «figuras» y de las «visualizaciones» en el empeño cognitivo

${ }^{4}$ Si bien Reguera y Muñoz aluden a la teoría de Wittgentein como «teoría de la figura», otorgando a esta teoría del lenguaje su debida generalidad y amplitud, nosotros hemos preferido denominarla «teoría visual del significado», enfatizando así la analogía visual de la que parte. En efecto, la versión inglesa de la sentencia [2.1] reza como sigue: «We make ourselves pictures of facts». Atendiendo a la definición del término «visualizar» que nos ofrece la Real Academia de la Lengua Española, así como al similar contenido semántico que comparten los verbos «to picture» y «visualizar», entendemos que la traducción alternativa, «Visualizamos los hechos», no sólo sería perfectamente legítima, sino incluso más adecuada a la lógica subyacente que tal teoría del significado nos propone.

La Real Academia de la Lengua Española ofrece cinco acepciones del término visualizar: 1. Visibilizar (Hacer visible artificialmente lo que no puede verse a simple vista, como con los rayos $\mathrm{X}$ los cuerpos ocultos, o con el microscopio los microbios); 2. Representar mediante imágenes ópticas fenómenos de otro carácter; p. ej., el curso de la fiebre o los cambios de condiciones metereológicas mediante gráficas, los cambios de corriente eléctrica o las oscilaciones sonoras con el oscilógrafo, etc.; 3. Formar en la mente una imagen visual de un concepto abstracto; 4. Imaginar con rasgos visibles algo que no se tiene a la vista; 5. Inform. Hacer visible una imagen en un monitor.

EMPIRIA. Revista de Metodología de Ciencias Sociales. N. . 22, julio-diciembre, 2011, pp. 113-140. ISSN: $1139-5737$ 
del ser humano, declarando al mismo tiempo la imposibilidad de excluir a las imágenes de una posible teoría del significado o del lenguaje. La sentencia constituye un axioma fáctico por cuanto afirma una cuestión de hecho, precisamente, el hecho de que visualizamos los hechos. En tan importante proposición están conjuntamente implicadas: a) la capacidad para la figuración o visualización que poseen los seres humanos; b) la alta frecuencia con la que utilizamos figuraciones y visualizaciones como modos de representación; y c) la esperanza de que mediante las figuraciones y visualizaciones podamos conocer y transmitir los hechos del mundo.

Para Wittgenstein, «El mundo es la totalidad de los hechos, y puede descomponerse en cada uno de ellos (como el lenguaje en proposiciones) para su análisis. Los hechos son estados de cosas existentes, y los estados de cosas, conexiones o combinaciones, sin más, de cosas u objetos» (Muñoz y Reguera, 2000:xiv). Así, esta conceptualización del mundo en tanto conjunto de hechos, y de los hechos en tanto combinaciones de cosas u objetos, es clave para comprender la funcionalidad cognitiva de las imágenes y, especialmente, de las fotografías, ya que éstas siempre muestran un conjunto de elementos, de cosas u objetos, combinados de una forma particular mediante una específica trama de conexiones. Es decir, el modo en que las fotografías muestran la realidad parece ser análogo al modo en el que se estructura el mundo en tanto conjunto de hechos, y los hechos en tanto estados o combinaciones de cosas u objetos. En este sentido, bastaría cambiar el término «cosa» por el de «sujeto» para aproximarnos al objeto central de la sociología, esto es, al mundo de las relaciones sociales.

En suma, según lo dicho, nos figuramos o visualizamos los hechos, es decir, estados de cosas, existentes o no existentes, definidos por las conexiones o combinaciones que se dan en una situación entre los diferentes objetos allí presentes. Así pues, «La figura es un modelo de la realidad» [2.12], pero también «La figura es un hecho» [2.141]. Para explicar esta última sentencia, Wittgenstein recurría al siguiente ejemplo: que este tintero esté sobre esta mesa puede expresar que yo estoy sentado en esta silla (Visser, 1999:145). En cualquier caso, las figuraciones o visualizaciones no se conciben como meros símbolos, ni siquiera como meras imágenes mentales, sino como hechos del mundo, lo que permite extender el análisis desde la lingüística hacia la pragmática. Las figuras son mundo, y no tan sólo representaciones del mundo. Siendo esto así, las ciencias sociales deben estudiar el universo icónico en tanto realidad en sí, por y para sí misma, es decir, en tanto hechos fundamentales de nuestro mundo. Ahora bien, esta necesidad de estudiar la cultura visual de nuestras sociedades no es el aspecto epistemológicamente más importante implícito en tal sentencia. No se trata tan sólo de que, según proclama Aaron Siskind, un intelectual y reconocido fotógrafo americano, «cada fotografía, como cada cuadro, debe ser valorado como un nuevo objeto que ha de ser contemplado por su propia belleza y sentido» (Howells, 2003:163). Se trata de que cada representación constituye, además de un objeto, un estado de cosas, una situación, es decir, un hecho en sí mismo. Así, en cualquier imagen fotográfica tomada en una reunión de amigos está im-

EMPIRIA. Revista de Metodología de Ciencias Sociales. N. ${ }^{\circ} 22$, julio-diciembre, 2011, pp. 113-140. ISSN: $1139-5737$ 
plícita la propia reunión de amigos, el contexto en el que se ha celebrado, los sujetos allí reunidos, la persona que tomó la foto, etc.

\section{Imagen y mundo: correspondencias elemental y estructural}

En el segundo grupo de sentencias Wittgenstein esboza una lógica de la representación, característica de las imágenes, que pretende aplicarse al sentido de las proposiciones lingüísticas. Esta lógica viene caracterizada esencialmente por los tres tipos de correspondencias que incorpora: una elemental, otra estructural y una tercera epistemológica. Se comentarán ahora las dos primeras, dejando para más adelante la tercera. Entre la figura y el mundo existe una correspondencia elemental, o punto a punto, entre los elementos de la figura y los objetos de la realidad [2.13]. Al igual que sucede en una fotografía, o en una pintura, cada elemento de la representación se corresponde con un objeto. La segunda correspondencia, o estructural, se hace posible porque los elementos de la figura están relacionados entre sí, al igual que también están relacionados entre sí los objetos del mundo.

Un conjunto de elementos, o de objetos, forma una configuración o estructura porque están dados comportándose unos con respecto a otros de una manera determinada [2.14]. Esta configuración constituye el estado de cosas u hecho que podemos figurar o visualizar, esto es, una determinada situación existente y real [2.202]. La correspondencia estructural afirma que el modo en que los elementos de la imagen se relacionan entre sí es el mismo modo en el que se relacionan entre sí los objetos. En la fotografía se da este tipo de correspondencia, pues todos los elementos de una imagen captan fundamentalmente una determinada situación en la que unos elementos se relacionan y comportan con respecto a otros ${ }^{5}$. En los hechos del mundo natural o social sucede lo mismo, que unos objetos o sujetos se relacionan y se comportan con otros en situaciones caracterizadas por una determinada estructura de interacción. La tesis de la correspondencia estructural está claramente expresada en la sentencia [2.15]. Si bien es necesario advertir que, para Wittgenstein, esta correspondencia estructural no se basa tan sólo en la similitud de las apariencias, sino que constituye una correspondencia esencialmente funcional. Están implicados los objetos pero, por encima de todo, los comportamientos recíprocos que mantienen los objetos entre sí, esto es, el estado de cosas que su configuración determina y que una determinada visualización muestra.

Una conocida fotografía de James Jarché, tomada en 1941, y titulada General Wavell watches his gardener at work, puede servir de ejemplo paradigmático en el que se que muestran este tipo de correspondencias. Allí puede verse un general vestido de uniforme, con ambas manos metidas en los bolsillos de su

\footnotetext{
${ }^{5}$ Esta correspondencia estructural no implica necesariamente que la «situación» descrita por una determinada imagen sea «verdadera». Esto es obvio, por ejemplo, en el caso de las fotografías «falsas» o de las imágenes puramente «virtuales». En el caso de las fotografías «escenificadas» existe un objeto referente real, pero ha sido artificialmente dispuesto para la toma.
}

EMPIRIA. Revista de Metodología de Ciencias Sociales. N. . 22, julio-diciembre, 2011, pp. 113-140. ISSN: $1139-5737$ 
pantalón, observando distendido cómo una joven negra empuja un cortacésped mecánico por su jardín. En primer lugar, ateniéndonos a los elementos humanos de la figura, existiría una correspondencia puntual entre los dos personajes representados y las dos personas reales. Ahora bien, los elementos de la imagen están puestos en relación uno con otro. Basta observar la mirada del general, dirigida hacia su jardinera negra, y la mirada resignada y perdida de ésta, dirigida hacia el suelo. Basta ver la pose del general, orgulloso, satisfecho, distendido, así como la de la joven, que en su tensión postural muestra el esfuerzo del trabajo, y en la leve inclinación de su cuerpo hacia delante su resignación. Además, por supuesto, a esta relación entre los elementos de la figura debe corresponder una relación análoga entre los objetos de la realidad. La fotografía transmite, mediante la substancia empíricamente concreta de una mera situación cotidiana, el profundo sentido de una relación de dominio existente en virtud de las posiciones sociales que ocupan ambos sujetos. Esto es, la fotografía muestra una específica situación cotidiana, pero en ella queda plasmada perfectamente una determinada estructura de interacción.

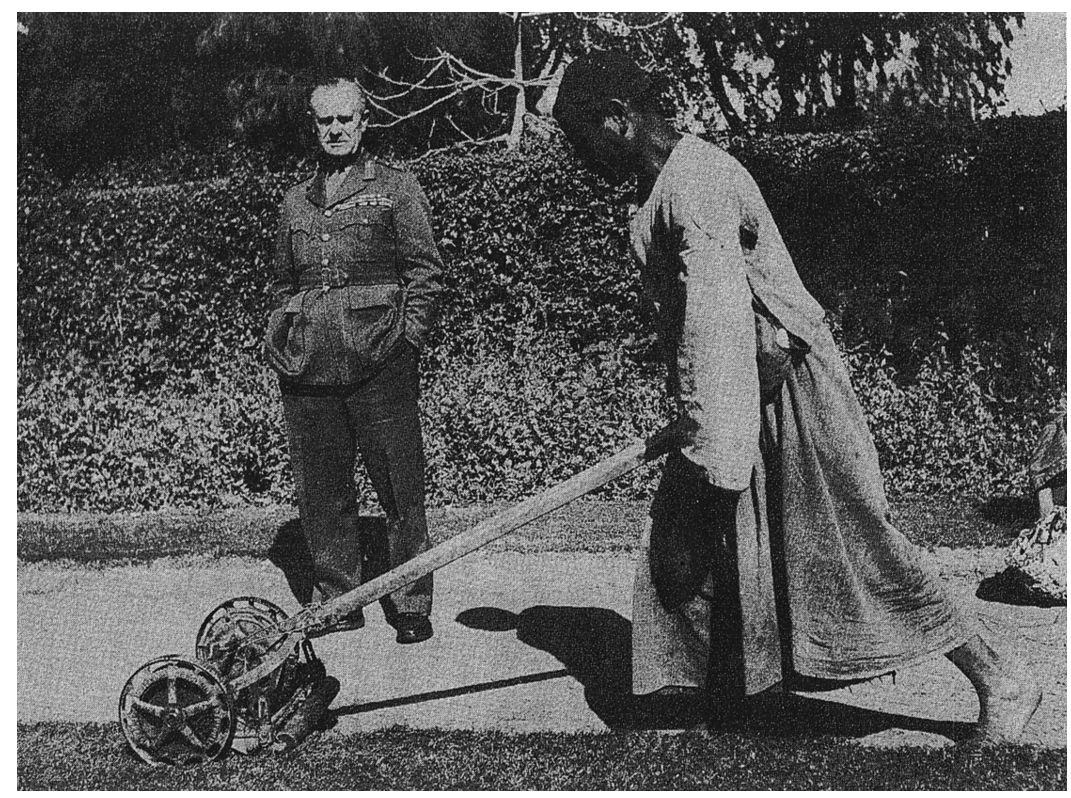

James Jarché, General Wavell watches his gardener at work (1941).

\section{La especificidad de los modos de representación}

En el tercer grupo de sentencias incluido en la tabla, Wittgenstein introduce otro concepto esencial, cual es el de las «formas de figuración», concepto al que nosotros también aludiremos y entenderemos como modos de representación. La correspondencia estructural que la figura es capaz de mostrar se debe a que su

EMPIRIA. Revista de Metodología de Ciencias Sociales. N. ${ }^{\circ}$ 22, julio-diciembre, 2011, pp. 113-140. ISSN: $1139-5737$ 
forma de figuración posibilita la representación de esa misma estructura [2.15]. Así, es evidente que el color no puede ser adecuadamente representado ni por una partitura musical, ni tampoco por una fotografía en blanco y negro. Aunque mediante la música puede hacerse una traducción emocional del color, al igual que mediante una fotografía en blanco y negro se traduce el color a una escala de grises, cada tipo de realidad exige una específica forma de figuración para poder ser adecuadamente representada. Esto es, la figura ha de tener algo en común con la realidad para poder figurarla [2.17], lo que nos indica que la relación epistémica entre las formas de figuración y las diferentes realidades del mundo no es contingente. Cada forma puede revelar el mundo haciendo visible, exclusivamente, sólo aquello representable y, por tanto, visualizable, desde su particular forma de figuración. Por tanto, desde cada uno de los modos de representación básicos utilizados por la ciencia, esto es, el lingüístico, el matemático y el icónico, podremos figurar o visualizar el mundo de una manera diferente, lo que constituye en sí un argumento clave a la hora de defender la necesidad de que las ciencias sociales utilicen también imágenes y/o visualizaciones de las realidades que investigan. Las ciencias sociales deben caminar hacia un formato de ciencia multimodal en el que se empleen los tres modos básicos de representación de la realidad, es decir, en el que se pongan simultánea pero ordenadamente en juego las palabras, los números y las imágenes.

El hecho fundamental de que cada forma de figuración, o cada modo de representación, visualice la realidad «a su modo y manera» abre el horizonte a una interpretación extensiva del término «figura». Desde esta perspectiva, las proposiciones lingüísticas representan los hechos del mundo, es decir, los narran, desde la lógica de su propia forma de figuración. Asimismo, las ecuaciones matemáticas, o las visualizaciones fotográficas, tan sólo pueden representar los hechos desde su propia forma de figuración. Ahora bien, si cada forma de figuración es sólo capaz de representar el mundo a su modo y manera, con cada modo de representación podremos ver diferentes aspectos del mundo. Aquello que podamos ver usando las palabras diferirá tanto de lo que podamos ver utilizando los números como de lo que veamos a través de las imágenes. Si cada forma de figuración representa el mundo a su modo y manera, el problema a resolver por la ciencia no sería tanto determinar cuál es el modo de representación ideal de la realidad, sino cuál es la naturaleza de cada forma de figuración, y qué mundo podemos ser capaces de captar con las representaciones, figuraciones o visualizaciones que emergen utilizando en cada caso una determinada forma.

\section{De las apariencias a las esencias}

En el cuarto grupo de sentencias encontramos una nueva propuesta de Wittgenstein. Aquí se afirma que toda figura, independientemente de su modo de representación, tiene una «forma lógica» que revela lo que la figura ha de tener en común con la realidad [2.18]. Todas las figuras son figuras lógicas, aunque no todas tienen por qué ser figuras visuales, espaciales, narrativas, matemáticas o acústicas [2.182]. Así, en la fotografía del General Wavell y su jardinera, el

EMPIRIA. Revista de Metodología de Ciencias Sociales. N. . 22, julio-diciembre, 2011, pp. 113-140. ISSN: 1139-5737 
modo de representación visual permite entrever una figura lógica de las relaciones de clase que trasciende las apariencias concretas representadas mediante la imagen. Ahora bien, debe subrayarse el hecho de que tal forma lógica o tal sentido de la figura nunca hubiera podido ser capturado sin la figuración o visualización concreta de esas apariencias. Esta unidad de lo concreto y de lo abstracto, de lo particular y de lo general, constituye en sí mismo un rasgo esencial de todas las imágenes, y especialmente de las fotografías en tanto iconos. Su naturaleza icónica, como podrá verse con mayor detalle en el siguiente epígrafe, permite establecer un sentido, capaz de mostrar la realidad del mundo más allá de las específicas conexiones existenciales directas que ha producido una determinada imagen o visualización. Ahora bien, el juego de estas específicas conexiones, que determinan su naturaleza en tanto índex, también es capaz de establecer figuras lógicas que definen un estado de la realidad.

Cuando Wittgenstein afirma que «la figura representa un posible estado de cosas en el espacio lógico» [2.202], debemos entender que la visualización de las apariencias que muestra una fotografía puede llevarnos a la visualización de las esencias, al menos en su forma lógica. Expresándolo en términos de John Tyndall, físico irlandés que descubrió por qué el color del cielo es azul, diríamos que aquello visto por los ojos del cuerpo nos puede mostrar algo que solo puede ser visualizado con los ojos del alma. (Visser,1999:139): Tanto en una fotografía que cita la realidad, como en una pintura que traduce esa misma realidad, las apariencias configuran un cuadro de la situación, o «hecho», que trascendiendo su contenido concreto prefigura lo que pueda ser su sentido, el sentido o significado último de tal representación. Como es obvio, esto también sucede con una novela o con cualquier otra narración, en la que el texto va tejiendo linealmente una propuesta de sentido. Asimismo, en la ecuación matemática, el cálculo específico que pueda realizarse aplicando valores concretos a sus parámetros, tampoco constituye la forma lógica en la que tal ecuación encuentra su sentido.

Tal y como anunciamos anteriormente, existe una tercera y última correspondencia, la epistémica, que vincula la forma lógica de una figura con la realidad por ella representada. De ahí que tanto la figura como su forma lógica puedan ser verdaderas o falsas, y serán una cosa u otra en función del grado de acuerdo o desacuerdo existente entre su sentido y la realidad [2.222]. Pero este acuerdo o desacuerdo entre la figura que representa un estado de cosas y la realidad sólo puede encontrarse en el espacio lógico [2.202]. Así, puede verse que, en este último conjunto de sentencias, se propone un salto epistemológico que legitima la posibilidad de conocer verdaderamente el mundo, posibilidad que constituye el núcleo de la tercera correspondencia, esto es, de la correspondencia epistémica.

El mundo puede ser conocido mediante la figura lógica que incorpora una visualización fotográfica, al igual que puede ser conocido mediante la figura lógica que pueda incorporar una narración lingüística o una formulación matemática. Ahora bien, es obvio que en todos estos casos el mundo será conocido cuando la figura se corresponda verdaderamente con la realidad. Entonces, y

EMPIRIA. Revista de Metodología de Ciencias Sociales. N. ${ }^{\circ}$ 22, julio-diciembre, 2011, pp. 113-140. ISSN: $1139-5737$ 
sólo entonces, podremos hablar de que las imágenes, al igual que las palabras o los números, producen y transmiten conocimiento sobre los hechos del mundo. En este punto es importante subrayar que las imágenes comparten el mismo destino que el resto de modos de representación, pues pueden llegar a ser tan falsas o banales como el sentido que muchas veces nos transmiten algunas palabras o algunos números. Por tanto, ningún modo de representación garantiza por sí mismo la producción de conocimiento verdadero. La dificultad del descubrimiento científico estriba precisamente en esto, en ser capaces de crear figuras lógicas que se correspondan verdaderamente con los hechos.

Así pues, según hemos visto, la teoría visual del significado de Wittgenstein parte de un axioma fáctico: que nos hacemos figuras o visualizamos los hechos. Establece, seguidamente, una lógica de la representación basada en la analogía visual y estructurada por tres correspondencias: la existente entre cada elemento y cada objeto; entre la configuración de los elementos y la de los objetos; y entre la figura lógica y la realidad. Considera, en tercer lugar, que las figuras lógicas están inscritas en todas las representaciones, aunque es preciso tener en cuenta que, si bien cada forma de figuración abre la posibilidad de representar el mundo, lo hará tan sólo a su modo y manera. Esto es, los tres modos de representación que estamos considerando, el lingüístico, el matemático y el icónico, figuran o visualizan el mundo, pero cada uno a su modo y manera. Por último, sostiene que todas las proposiciones, independientemente de su modo de representación, pueden ser verdaderas o falsas, y serán una u otra cosa según exista o no correspondencia entre su figura lógica o sentido y la realidad que pretenden representar.

En suma, tal y como se expone más ampliamente en la segunda parte de este artículo, la teoría visual del significado explicita epistemológicamente las dos posibilidades analíticas que se abren a la hora de incorporar las imágenes (imágenes como índices, imágenes como iconos) a los procesos de creación de conocimiento científico-social. En primer lugar, las fotografías nos ofrecen una correspondencia entre elementos de la imagen y los objetos de la realidad. Esta correspondencia, estrictamente vinculada a su naturaleza de índex, esto es, de signo que nos indica la presencia o la existencia de algo, nos permite establecer adecuados registros empíricos, nos permite establecer hechos y nos permite producir datos con un grado de fiabilidad y validez excepcional. En segundo lugar, las imágenes fotográficas, en virtud de la correspondencia estructural que establecen en tanto iconos, son especialmente aptas para mostrar cuadros de situación configurados por un amplio entramado de relaciones, es decir, para llegar a comprender situaciones o hechos sociales de gran complejidad.

Finalmente, subrayaremos el hecho de que aceptar la teoría visual del significado no implica asumir que todas las figuras deban ser «imágenes». En la teoría visual del significado está implícito el hecho de que existen visualizaciones de muy diverso tipo. En concreto, puede afirmarse que la figura, al menos la figura lógica, no tiene tanto que ver con la descripción de las apariencias, cuanto con las descripción funcional de los desempeños (Biggs, 2004). Los elementos

EMPIRIA. Revista de Metodología de Ciencias Sociales. N. . 22, julio-diciembre, 2011, pp. 113-140. ISSN: $1139-5737$ 
y los objetos se relacionan entre sí pero, al igual que en la relación mostrada entre el General Wavell y su jardinera, esto significa que interactúan, esto es, que se comportan recíprocamente de una manera peculiar y determinada. La formación de ingeniero recibida por Wittgenstein parece que influyó a la hora de elegir la imagen (bild, picture) como la figura de referencia de su teoría del significado. Así, en el dibujo técnico realizado por un ingeniero o por un arquitecto está implícita la teoría visual del significado, pues en estos dibujos se dan las tres correspondencias básicas. Por ejemplo, el diagrama que representa un circuito electrónico define exactamente el comportamiento de sus elementos-objetos. Ahora bien, lo que Wittgenstein aprendió de su formación de ingeniero no se limitó a un particular estilo de representación, sino que le mostró los principios que subyacen a todos nuestros modos de representación (Biggs, 2004:300), lo que explica que aplicara la analogía visual a su teoría general del significado.

\section{EVIDENCIAS Y SENTIDOS: LA TEORÍA DE LA COHERENCIA DE LAS IMÁGENES DE JOHN BERGER}

En su ensayo clave sobre la fotografía, incluido en el libro Otra manera de contar, John Berger reflexiona sobre la naturaleza de las imágenes considerando especialmente tanto sus problemas como sus capacidades de significación. Berger explora así la posibilidad de contar historias exclusivamente a través de imágenes, bien sean fotografías, bien cuadros de pintura. Partiendo de una visión de la imagen en tanto apariencia, y de un rasgo esencialmente vinculado a ella, como es la ambigüedad, avanza una propuesta para desentrañar el enigma que encierra toda imagen, esto es, para encontrar atisbos de significación tanto en la imagen fija aislada como en un determinado conjunto de imágenes. Denominaremos a esta propuesta teoría de la coherencia de las imágenes, puesto que sostiene la posibilidad de significación de cualquier imagen atendiendo a las coherencias que natural y culturalmente nos ofrece toda apariencia. Desde esta perspectiva teórica, Berger concluye señalando que las imágenes pueden llegar a constituir un semi-lenguaje, es decir, que pueden transmitir ideas, significados y sentidos. Como veremos, los vínculos que existen entre esta propuesta y la lógica del modo de representación visual, esbozada por Wittgenstein, se ponen de manifiesto en el hecho de que la «coherencia» capaz de otorgar sentido a las imágenes opera en el marco de una intrínseca y extrínseca «configuración» de sus elementos-objetos.

Berger parte de un hecho fundamental que explica en gran medida los problemas semánticos o de significación que caracterizan a las imágenes, así como los problemas que, por este motivo, comporta su incorporación a la investigación social: todas las fotografías son ambiguas (Berger, 2008:91). Berger también nos ofrece una razón que explica la inmanente ambigüedad de las imágenes: «una fotografía aísla las apariencias de un instante inconexo», mientras que en la vida el significado no es instantáneo, sino que se produce mediante el despliegue de una

EMPIRIA. Revista de Metodología de Ciencias Sociales. N. ${ }^{\circ}$ 22, julio-diciembre, 2011, pp. 113-140. ISSN: $1139-5737$ 
historia, esto es, con su concurso (Berger, 2008:89). La fotografía, nacida de la discontinuidad, y producto de una única elección, es débil tanto en intencionalidad como en significado. Esta convicción en la ambigüedad y polisemia de las imágenes se corresponde, en la obra de Barthes, con su aserto de que la fotografía constituye un «mensaje sin código» (Barthes, 1989). Barthes es muy consciente de que una fotografía está atravesada por múltiples códigos, pero dado que no todos ellos pertenecen a un mismo sistema semiótico, el potencial significativo de las imágenes queda inmerso en el contexto de una complejidad semiótica que dificulta la determinación o especificación del mensaje.

La imagen, en tanto icono, siempre parece requerir apoyos externos para determinar su significado. Ahora bien, Berger señala que, paradójicamente, cuando una fotografía es utilizada con palabras, juntas pueden llegar a producir un efecto de incuestionable certeza o, incluso, de afirmación dogmática (Berger, 2008:9192). También nos dice que con el concurso de un conjunto de imágenes la especificación del significado puede ser mucho mayor. Esto es, los problemas de significación asociados a la fotografía pueden resolverse, en gran parte, utilizando esencialmente tres fórmulas de complementación entre los distintos modos, esto es, utilizando imágenes con palabras $(\mathrm{I}+\mathrm{P})$; imágenes con imágenes $(\mathrm{I}+\mathrm{I})$; e imágenes con números $(\mathrm{I}+\mathrm{N})$. En este sentido, puede recordarse el hecho, habitual en las ciencias sociales, de que tanto los procesos como los resultados de una investigación cuantitativa suelen ir acompañados de una extensa y prolija narración. Asimismo, todas las narrativas que produce la ciencia social suelen estar afectadas por pretensiones métricas que, explícita o implícitamente, vinculan la naturaleza cualitativa de los fenómenos investigados con algún tipo y/o grado de medición. Es decir, también el sentido de una representación matemática de la realidad puede ser especificado mediante una narración, así como el sentido de una representación narrativa puede quedar igualmente especificado por una conveniente cuantificación. La potencial complementariedad entre los tres modos básicos de representación que utiliza la ciencia, es decir, entre el icónico, el matemático y el narrativo, establece un argumento epistemológico clave a favor de una ciencia social multimodal que utilice simultáneamente imágenes, palabras y números.

Berger afirma que la fotografía es débil en significado pero, sin embargo, al mismo tiempo también afirma que la fotografía es irrefutable en tanto evidencia. La doble naturaleza de este formato de visualización, icónica e indéxica, explicaría esta paradoja o aparente contradicción. «Se dice que la cámara no puede mentir, porque la fotografía no tiene lenguaje propio, porque cita más que traduce. No puede mentir porque imprime directamente». En sí misma, la fotografía no puede mentir, pero, por la misma razón, no puede decir la verdad; o mejor dicho, la verdad que puede defender por sí misma es limitada (Berger, 2008:9697). Este grado de verdad depende, en primer término, del uso al que esté orientada una imagen, sea científico, de vigilancia o comunicativo. Así, «la investigación científica utiliza la fotografía: en medicina, en física, meteorología, astronomía, biología», y «cuando se utiliza una fotografía científicamente, su evidencia incuestionable representa una ayuda para llegar a una conclusión:

EMPIRIA. Revista de Metodología de Ciencias Sociales. N. ${ }^{o}$ 22, julio-diciembre, 2011, pp. 113-140. ISSN: $1139-5737$ 
suministra información dentro del marco conceptual de una investigación». Por el contrario, en una fotografía utilizada «como medio de comunicación, la naturaleza de la experiencia vivida se ve implicada y en este momento la verdad se vuelve más compleja» (Berger, 2008:98). Los usos científicos y comunicativos a los que alude Berger pueden ser equiparados, respectivamente, en el marco de la clásica división metodológica, a usos científico-cuantitativos y a usos científico-cualitativos, lo que nos ofrece un panorama dual a la hora de incorporar la fotografía a la investigación realizada por las ciencias sociales.

La fotografía utilizada en tanto evidencia empírica no se enfrenta del mismo modo a los problemas de significación derivados de la necesidad de establecer un sentido. Antes bien, se enfrenta a la necesidad de configurar su significado estableciendo y verificando un conjunto de determinadas relaciones de hecho. Aquí, la naturaleza de índex de la fotografía se aproxima, en cierta forma, a la lógica del modo de representación numérico, cuyas formulaciones matemáticas no deben necesariamente ser «comprendidas» en términos de algún significado o sentido lingüístico que transcienda el conocimiento que las relaciones cuantitativas implícitas en la propia ecuación establecen por sí mismas. Por el contario, cuando el objetivo de la investigación dependa de la comunicación con imágenes o del establecimiento de adecuados análisis cualitativos, es obvio que los problemas vinculados con la ambigüedad de las imágenes estarán más vinculados a la lógica del modo de representación lingüístico, cuyas narraciones configuran estructuralmente su sentido más allá de cualquier tipo de cuantificación.

En suma, y de acuerdo con la clasificación de signos establecida por Charles S. Peirce, lo que constituye el gran problema o pecado original de las imágenes, es decir, la imposibilidad de constituir un sistema convencional de significación capaz de precisar significados (lenguaje), encuentra una solución necesariamente dual debido a la doble naturaleza de la fotografía. La resolución última del dilema de la significación de las imágenes (las fotografías significan mucho y nada al mismo tiempo) depende de una consideración claramente diferenciada de la fotografía en tanto índex y en tanto icono. Solamente desarrollando usos científicos especializados que se ajusten a la propia naturaleza de los índex o de los iconos se podrá seguir avanzando en la incorporación de la imágenes a los procesos de investigación social.

\section{La fotografía como un índex}

Sabemos que Peirce distinguió entre el orden del índex (representación por contigüidad física del signo con su referente), el orden del icono (representación por semejanza), y el orden del símbolo (representación por convención general). En el índex Peirce «toma en cuenta no el producto icónico acabado sino el proceso de producción del mismo» (Dubois, 1986: 48) y, en este sentido, la fotografía constituye una huella luminosa, de ahí que su carácter de signo esté emparentado con la huella, la marca, el depósito, el humo, la sombra, la cicatriz, la ruina o el síntoma. «Todos estos signos tienen en común «el hecho de ser realmente afectados por su objeto» (Peirce, 2.248), de mantener con él «una relación

EMPIRIA. Revista de Metodología de Ciencias Sociales. N. ${ }^{\circ}$ 22, julio-diciembre, 2011, pp. 113-140. ISSN: $1139-5737$ 
de conexión física» (3.361), y en esto se distinguen tanto de los iconos, que muestran una semejanza, como de los símbolos, tales como las palabras, que significan por convención general (Dubois, 1986:48).

El índex, para Peirce, está regulado constitutivamente por cuatro principios: conexión física; singularidad; atestiguamiento y designación. Dada la conexión existencial directa que existe entre el signo y el objeto, y dado su carácter de huella, el índex designa un objeto o un ser particular, en una situación particular, en lo que tiene de absolutamente individual y, por este motivo, siempre es único. El índex certifica, ratifica y autentifica, aunque esto no quiere decir que signifique, tan sólo que da cuenta de una existencia, que atestigua. Por último, estaría el carácter designativo del índex, que indica o señala con el dedo, diciendo «allí», esto es, mostrando una determinada situación. Estos son los cuatro principios o rasgos que deben considerarse especialmente a la hora de establecer usos científico-positivos de la fotografía, usos que en cualquier caso utilizarán como base informativa las conexiones existenciales directas que los índices siempre mantienen con la realidad, y que en cualquier caso deberán operacionalizar científicamente las marcas, las huellas o las indicaciones que los objetos impriman en la fotografía o en cualquier otro espacio de representación visual.

André Bazin, un intelectual francés autor de La ontología de la imagen fotográfica, fue el primero en reflexionar sobre el hecho de que una fotografía es fundamentalmente una huella. A diferencia del dibujo, «la imagen fotográfica se produce instantáneamente mediante la reflexión de la luz; su figuración no está impregnada de experiencia ni de consciencia» (Berger, 2008:95). La fotografía como huella se comprende si la comparamos con el dibujo. «En un dibujo, una manzana se hace redonda y esférica; en una fotografía, la redondez, la luz y la sombra de la manzana se acepta como algo sabido». «El fotógrafo elige el árbol, la escena que él desea, el tipo de película, el enfoque, el filtro.... Pero donde no interviene -ni puede intervenir sin cambiar el carácter fundamental de la fotografía- es en la luz que emana del árbol al atravesar la lente y la huella que deja sobre la película» (Berger, 2008:93). De ahí la enorme diferencia que existe entre la pintura, que traduce la realidad, y la fotografía, cuya concreta visualización más bien cita una determinada realidad.

Las fotografías constituyen «signos que no significan, hablando con propiedad, nada por sí mismos, sino que la significación está determinada por su relación efectiva con su objeto real, que funciona como su causa y como su referente. Son las leyes físicas las que rigen la conexión entre el signo y su objeto» (Dubois, 1986:58). Dubois, otro de los autores que también subraya las limitaciones de la imagen para determinar un significado preciso, nos dice que «la fotografía afirma ante nuestros ojos la existencia de aquello que representa (el «eso ha sido» de Barthes), pero no nos dice nada sobre el sentido de esa representación; no nos dice «esto quiere decir tal cosa»». «Como índex, la imagen fotográfica no tendría otra semántica que su propia pragmática», y este es precisamente el gran problema, según Dubois (Dubois, 1986:50). Considerando la

EMPIRIA. Revista de Metodología de Ciencias Sociales. N. ${ }^{o}$ 22, julio-diciembre, 2011, pp. 113-140. ISSN: $1139-5737$ 
fotografía en tanto índex, es obvio que «su único sentido, si se quiere, es precisamente indicar, subrayar, mostrar su relación singular con una situación referencial determinada». También Peirce mantenía que «el índex no afirma nada, dice sólo Allí’ (Dubois, 1986:70-71). Ahora bien, desde la perspectiva de la incorporación de las imágenes en tanto índex a los procesos de investigación social, antes que un gran problema, la vinculación existencial directa entre signo y objeto constituye su gran virtud. La potencia significativa que esta cualidad incorpora puede vincularse al valor epistemológico de una de las sentencias wittgensteinianas anteriormente consideradas: «la figura es un hecho». En suma, el sentido de la representación fotográfica estaría íntimamente vinculado a su existencia o a su pragmática

La fotografía en tanto índex constituye un indicador de la existencia de una determinada situación, hecho u objeto, y aunque Peirce señala que, en tanto tal, no puede decirnos nada acerca de la naturaleza de tal objeto, ha de tenerse en cuenta que el quehacer común de todas las ciencias consiste fundamentalmente en registrar, producir, analizar e interpretar indicaciones de la realidad. Ha de considerarse también que las ciencias naturales y sociales no tienen siempre por objeto revelar la «naturaleza» o la «esencia» de los fenómenos sino, antes bien, descubrir pautas o estructuras relacionales que puedan darse entre los objetos y hechos del mundo. Es obvio que en todas las ciencias sociales la investigación mediante indicadores tiene una trascendencia y alcance que va mucho más allá de los estudios calificados a sí mismos como de «indicadores sociales». Cualquier investigación económica, sociológica o psicológica que utilice datos cuya verosimilitud se base en la verosimilitud de la conexión existencial que exista entre el dato y algún aspecto de la realidad, sea económica, sociológica o psicológica, está trabajando con indicadores, esto es, con índices o índex de esa realidad. En este sentido, la fotografía tan sólo se distingue del resto de índex por el hecho de constituir, en tanto dato, una estructura compleja de indicadores dispuesta en el marco espacial de una imagen.

Llegados a este punto, podríamos hacernos una idea de la potencialidad científica de las imágenes si, a través del concepto de índex, y de su naturaleza básica, esto es, de la conexión existencial directa existente entre el signo y el objeto, generalizamos la idea de fotografía para incluir también cualquier otro tipo de visualización, y no solo aquéllas que reproduzcan miméticamente las apariencias visuales tal y como son percibidas por nuestros ojos. El concepto amplio de visualización, o índex fotográfico, que se correspondería con el contenido semántico establecido por la Real Academia para el término visibilizar (hacer visible artificialmente lo que no puede verse a simple vista), establece un nuevo horizonte potencial de representaciones visuales creadas mediante procesos en los que se mantiene una conexión existencial o una concatenación causal entre un hecho y su signo. Desde este punto de vista, todas estas visualizaciones estarían configuradas como marcas físicas o huellas de la realidad. Desde esta ampliación conceptual del significado de una imagen, debería entenderse que, por ejemplo, un termómetro analógico nos ofrece, mediante el

EMPIRIA. Revista de Metodología de Ciencias Sociales. N. ${ }^{\circ} 22$, julio-diciembre, 2011, pp. 113-140. ISSN: $1139-5737$ 
establecimiento de una marca de mercurio en una escala, una específica visualización del estado calórico particular de un determinado cuerpo.

Ahora bien, ha de considerarse que la mayoría de las visualizaciones que la ciencia actual está utilizando suelen ser mucho más complejas que la imagen configurada por la altura que alcanza una columna de mercurio. Las actuales visualizaciones científicas son el resultado de la aplicación de complejos algoritmos a determinadas bases de datos (Hansen y Johnson, 2005). Estos algoritmos que se utilizan para crear visualizaciones científicas pueden ser pensados primariamente como una transformación de un tipo de dato en otro. Los sistemas de visualización científica, en cuyo corazón se encuentra el algoritmo, transforman los datos en diferentes formatos y, en último término, los transforma en una representación que puede ser visualizada en un sistema de ordenador (Schroeder y Martin, 2005:3). En este sentido, también la fotografía, como se pone de manifiesto en el procesamiento matemático de la imagen digital, constituye una específica visualización generada mediante la aplicación de determinados algoritmos a las manifestaciones lumínicas de un objeto de la realidad.

En suma, la idea de unos algoritmos que transforman datos en representaciones visuales, teniendo en cuenta la importancia que estas tienen en todo proceso científico, explica, justifica y abre un amplísimo horizonte a la hora de utilizar figuraciones y visualizaciones en la ciencia y, por supuesto, también en la ciencia social. Desde esta perspectiva, el propio concepto de «apariencia» adquiere un mayor alcance, ya que la visualización queda liberada de la mera representación «mimética» $\mathrm{o}$ «naturalista» que tal concepto habitualmente incorpora. Así, una consideración final se impone: más allá de la obvia posibilidad y necesidad de incorporar la fotografía a los procesos de generación de conocimiento social, todavía es mucho más importante que las ciencias sociales, al igual que están realizando ya las ciencias naturales, desarrollen el enorme potencial científico implícito en la visualización de la realidad. Por este motivo, las ciencias sociales deben ser capaces de incorporar representaciones visuales, miméticas o no, en sus procesos de investigación. En este sentido, las grandes resistencias que ha mostrado y sigue mostrando la sociología a la incorporación de la fotografía como un tipo de indicador visual constituye un mero ejemplo de la gran resistencia que, en general, oponen todos los sociólogos al empleo científico de cualquier tipo de visualización.

\section{La fotografía como un icono}

Berger, tras reconocer que la ambigüedad de las apariencias limita seriamente la transmisión de significados, se pregunta si tendría algún sentido pensar que las apariencias puedan constituir una estructura lingüística capaz de transmitir mensajes o ideas que transciendan la referencia empírica particular que toda fotografía, en tanto huella o índex, cita. Y la respuesta que ofrece a esta pregunta es que la coherencia de las imágenes propone una unidad similar a la de un lenguaje, una especie de semi-lenguaje. Una fotografía que cita la realidad no puede quedar totalmente explicada mediante la suma de significados que podrí-

EMPIRIA. Revista de Metodología de Ciencias Sociales. N. . 22, julio-diciembre, 2011, pp. 113-140. ISSN: $1139-5737$ 
an derivarse de los múltiples sistemas semiológicos aplicables a todas las apariencias que la imagen incorpora. Mediante la consideración de esta suma semiológica no podríamos descubrir, por ejemplo, por qué una determinada imagen nos conmueve de una manera determinada. Tampoco podríamos entender cuál es específicamente el parecido o la semejanza con el mundo que tal fotografía o imagen nos transmite en tanto icono.

Las apariencias son o pueden llegar a ser coherentes en virtud, según Berger, de las afinidades, de las imitaciones y de las asociaciones visuales. En primer lugar, pueden ser coherentes merced a las afinidades visuales que podemos encontrar en el parecido existente entre muy diversas formas estructurales del mundo (un trozo de roca puede parecer una montaña; la hierba crece como el pelo; la nuez queda constreñida en su cáscara como el cerebro en su cráneo; todas las patas/pies se parecen). Las apariencias también pueden ser coherentes porque los seres vivos establecen múltiples imitaciones visuales, de modo que las apariencias ya no sólo establecen distinciones entre los objetos y/o sucesos, sino que también, como sucede en el camuflaje natural, establecen importantes similitudes. Por último, las apariencias son coherentes porque en el interior de la mente se producen múltiples asociaciones visuales, pues siempre la visión de un objeto y/o suceso entraña la visión de algún otro objeto y/o suceso (Berger, 2008:111-114). En suma, una fotografía que cita la realidad contiene un significado potencial que emerge, en parte, de la agregación mecánica de los significados que se derivan de los múltiples sistemas semiológicos aplicables a las apariencias que incorpora la imagen pero, fundamentalmente, de la coherencia implícita en la imagen merced a las afinidades, imitaciones y asociaciones visuales que sugiere o comporta. Son estas múltiples conexiones sincrónicas, que establecen la coherencia de una imagen, las que pueden llegar a constituir, en opinión de Berger, una especie de semi-lenguaje capaz de transmitir una idea o un significado.

Ahora bien, es evidente que las conexiones que puedan establecerse entre las múltiples apariencias que incluye una imagen están integradas en el seno de una estructura compleja, por lo que la coherencia subyacente a una imagen, y así el significado o el sentido que contenga o transmita, ha de ser necesariamente revelado mediante el concurso de un intenso proceso de búsqueda. Berger nos dice que «las apariencias son tan complejas que sólo la búsqueda, inherente al acto de mirar, puede extraer una lectura de su coherencia subyacente». «En las apariencias todo lo que se puede leer está ya ahí, pero de un modo no diferenciado. Es la búsqueda, con sus opciones, lo que establece la diferencia. Y lo visto, lo revelado, es hijo tanto de las apariencias como de la búsqueda» (Berger, 2008: 118). Es decir, que sólo mediante una búsqueda previa, capaz de revelar las coherencias subyacentes a una, o a un conjunto de imágenes, puede abordarse una utilización icónica susceptible de ser incorporada a procesos de investigación, fundamentalmente cualitativos, típicos de las ciencias sociales. Dado que una buena parte de las investigaciones sociológico-visuales, pretendidamente icónicas, omiten o prestan escasa atención a este tipo de búsqueda, debe insistirse en la necesidad

EMPIRIA. Revista de Metodología de Ciencias Sociales. N. ${ }^{\circ} 22$, julio-diciembre, 2011, pp. 113-140. ISSN: $1139-5737$ 
de que cualquier utilización icónica de una imagen, o de un conjunto de imágenes, en la investigación social, se lleve a cabo con el concurso de una adecuada estructuración metodológica de esta búsqueda.

Siguiendo la línea argumental de Berger, también debe tenerse en cuenta el hecho de que no todas las imágenes contienen coherencias suficientemente ricas como para constituir con ellas un semi-lenguaje capaz de transmitir algún significado o idea utilizable en la producción científica de conocimiento social. Algunas fotografías citan la realidad muy pobremente, mientras que otras, por el contrario, constituyen citas extensas de esa misma realidad, citas que, por tanto, pueden llegar a ser capaces de satisfacer la expectativa de significado o sentido que tenemos al mirar cualquier imagen. Ni todas las fotografías tiene el suficiente valor icónico, ni el contenido icónico de cualquier fotografía se ajusta a la estructuración de la búsqueda establecida en un determinado proceso de investigación. Por tanto, la selección de las imágenes que deban ser incorporadas a un proceso de investigación constituirá siempre un aspecto clave del diseño de tal proyecto investigador.

Cuando una fotografía, pese a la simplificación que siempre incorpora, y pese al corte sincrónico del que nace, es capaz tanto de establecer una dimensión narrativa en la situación o suceso que registran sus apariencias, como de mostrar mediante las conexiones que establece una adecuada coherencia, entonces también será capaz tanto de ampliar y añadir densidad a su significado, como de aportar una idea general que trascienda la estricta particularidad de las apariencias que muestra. Sólo cuando las fotografías citen extensamente la realidad, el conjunto de sus correspondencias puede llegar a formularse como una idea. En estos casos las fotografías articularían icónicamente una idea general aportando un conocimiento que trasciende la específica materialidad que incorpora cualquier imagen fotográfica. Esta observación es importante para las ciencias sociales porque la calidad de una investigación visual, de naturaleza icónica, dependerá en gran parte de la calidad de las imágenes que se analicen o que se produzcan en una determinada investigación. En suma, de una investigación visual que utilice imágenes que no citan extensamente la realidad, así como de una investigación visual que no establezca una adecuada búsqueda de la coherencia, no pueden esperarse resultados relevantes.

La idea general mediante la que Peirce caracteriza la naturaleza icónica de los signos es la de similitud o semejanza, si bien esta puede ser la del extremo parecido visual que incorpora una fotografía, o puede ser la de un parecido mucho más sutil, como el que incorpora una analogía. Según Peirce existen tres clases de iconos, de acuerdo con el tipo de similitud que opera en cada uno de ellos: en la imagen opera la semejanza visual; en los diagramas se proyecta una analogía de la estructura de relaciones; en la metáfora, por último, la similitud queda establecida mediante el concurso de un tercer término. Por supuesto, los tres tipos de iconos son aplicables al contenido semántico que incorpora una fotografía y, por supuesto, los tres tipos de contenido pueden ser utilizados convenientemente en el proceso de una investigación social.

EMPIRIA. Revista de Metodología de Ciencias Sociales. N. . 22, julio-diciembre, 2011, pp. 113-140. ISSN: $1139-5737$ 
La idea fundamental, para Peirce, es que el icono participa del carácter del objeto que representa [Peirce, 4.531 ] y, siendo esto así, se colige que mediante la observación directa del icono pueden revelarse otras verdades referentes a ese mismo objeto. Este rasgo epistemológico de los iconos es determinante, pues legitima la posibilidad de utilizar imágenes, diagramas y/o metáforas en la extracción de conocimiento. En la medida que el icono participa de la naturaleza del objeto representado, las verdades reveladas mediante el análisis del icono podrán ser también verdades aplicables a su objeto de referencia. Así, al menos algún rasgo de la personalidad o del carácter de un individuo puede quedar reflejado en cualquier retrato fotográfico. Ahora bien, en los magníficos retratos de August Sander pueden verse aspectos esenciales de la naturaleza del tipo social fotografiado6. Analizando Las Meninas, sin duda el cuadro más complejo y fascinante pintado por Velázquez, Foucault extrajo aspectos esenciales de la naturaleza de la pintura y de cualquier representación visual. Innumerables ejemplos podrían añadirse a los dos citados, pero lo importante es subrayar que, en la medida de que el icono participa de la naturaleza y de la vida de un objeto, suceso o situación, las inferencias que puedan hacerse desde el icono serán también inferencias válidas para tal objeto, suceso o situación. De este modo quedaría epistemológicamente justificado el uso icónico de las imágenes en la investigación social, pues el análisis pormenorizado de las mismas podría aportarnos, no solamente conocimientos veraces sobre el objeto de estudio, sino también conocimientos suplementarios, esto es, conocimientos que no hubieran podido ser obtenidos sin el análisis de tales imágenes.

Berger nos ofrece varios ejemplos de fotografías capaces de transmitir una idea general, esto es, de constituir esa especie de semi-lenguaje en el que se despliegan las coherencias sincrónicas de una determinada imagen. Uno de estos ejemplos de cita extensa es la fotografía de André Kertész, titulada Partida de un húsar rojo, junio de 1919, Budapest $t^{7}$ (Berger, 2008: 101-9). La fotografía representa una situación en la que un soldado y una mujer con un bebé en sus brazos se despiden mirándose fijamente a los ojos, congelando lo que tal mirada capta para poder llevarse, tras la partida, una indeleble imagen del otro. El contraste entre la ropa de estar en casa que lleva la mujer y el uniforme destinado a la batalla que lleva el hombre define el drama que allí se está viviendo. El contexto en el que ambas miradas se cruzan está plagado de referencias históricas, tal y como indica el propio título de la fotografía. En la foto se pueden ver muchas cosas, el cuartel al fondo, otros soldados que asisten a ese mirar, el hijo que mira a su padre, los árboles que se mueven al fondo. Pero este juego completo de referencias no hacen sino resaltar la mirada que congela el tiempo, la idea de quietud que se transmite cuando todo parece estar en movimiento, cuando el drama de la separación está a punto de producirse. Todos los contrastes que incor-

\footnotetext{
${ }^{6}$ Véanse, a modo de ejemplo, algunos de sus retratos: http://www.artphotogallery.org/02/artphotogallery/photographers/august_sander_01.html

${ }^{7}$ Fotografía incluida en el citado libro de Berger.
}

EMPIRIA. Revista de Metodología de Ciencias Sociales. N. ${ }^{\circ}$ 22, julio-diciembre, 2011, pp. 113-140. ISSN: $1139-5737$ 
poran los dos personajes principales del cuadro, como sus ropas, su pose o sus manos, transmiten muy adecuadamente el sentido de una partida, una idea universal que Kertész capta desde las apariencias concretas de una huella. En toda despedida, parece decirnos la imagen, existe un encuentro; en todo movimiento, una quietud.

En suma, la coherencia de las imágenes ha de entenderse en cualquier caso como el estado conjunto de las correspondencias implícitas en una figuración icónica, sea ésta una imagen, un diagrama o una metáfora. Así, según Berger, el corte trasversal que establece la fotografía nos permite ver la interconexión y la coexistencia de los sucesos. Las correspondencias que derivan de la unidad de las apariencias compensan entonces la ausencia de secuencia que, como se recordará, era la causa fundamental que determinaba la ambigüedad de las imágenes. Entonces, esta unidad coherente de las correspondencias posibilita que tal conjunto de apariencias particulares articulen una idea general.

Es obvio que esta teoría de la coherencia de las imágenes guarda una íntima similitud con la teoría visual del significado de Wittgenstein. Pero el filósofo va incluso más allá pues, para él, la configuración de los elementos de una imagen, así como de los objetos del mundo, constituye la parte dinámica de la realidad que se manifiesta en la creación o destrucción de situaciones posibles de existencia, de estados de cosas u hechos, de diversas configuraciones (Wittgenstein: «El objeto es lo fijo persistente, la configuración es lo cambiante, inestable» [2.0271]; «La configuración de los objetos forma el estado de cosas» [2.0272]). Por tanto, según lo dicho, las fotografías no serían capaces tan sólo de transmitir ideas, como bien sugiere Berger, sino también, como sugiere Wittgenstein, de mostrarnos, mediante sus configuraciones, la realidad de los sucesos u hechos del mundo.

Una sola fotografía, según Berger y Wittgenstein, es capaz de mostrarnos tanto ideas como hechos. Pero es obvio que tan sólo una, por mucho interés que tenga, no constituye material suficiente para el despliegue de un adecuado proceso científico de investigación social. Al igual que unas imágenes pueden usarse junto con otras para configurar una historia con sentido, también pueden utilizarse para alcanzar unos buenos resultados de investigación. La potencia de una imagen se amplía por medio de la combinación con otras imágenes, por lo que la capacidad de un grupo de imágenes para relacionar lo particular con lo general es mucho mayor que la de una imagen única. Con tan sólo cuatro imágenes, nos dice Berger, se puede expresar algo de forma más precisa que con una (Berger, 2008:281-4). La posibilidad de establecer una narración con sentido se encuentra en el montaje de las imágenes, que Berger, siguiendo al cineasta ruso Sergei Eisenstein, denomina «montaje de atracciones». En este montaje las imágenes se acoplan entre sí mediante contrastes, equivalencias, conflictos y recurrencias. Un montaje que, a diferencia del cinematográfico, no define una ordenación temporal o serie prefijada, sino que establece encuentros de imágenes en el espacio, esto es, en el orden de la simultaneidad. Este montaje de atracciones destruye el concepto de «secuencia», pero reintegra las fotografías a un contexto vivo y de ex-

EMPIRIA. Revista de Metodología de Ciencias Sociales. N. . 22, julio-diciembre, 2011, pp. 113-140. ISSN: $1139-5737$ 
periencia, «de ahí que su ambigüedad por fin deviene verdadera. Permite que el pensamiento se adueñe de lo que muestran...». Finalmente, «Las apariencias devienen lenguaje de una vida vivida» (Berger, 2008, 289).

Ahora bien, los conjuntos de fotografías no sólo pueden ser utilizados para contar historias o, incluso, como en este último caso, para reflejar un cuadro de la situación social y vital de algunas personas. Los conjuntos de fotografías pueden y deben ser integrados perfectamente en procesos completos de investigación, tal como hiciera Erving Goffman analizando las fotografías de mujeres utilizadas por la publicidad (Goffman, 1979), o John Grady estudiando el cambio en las actitudes racistas de los americanos mediante el análisis de una muestra representativa de fotografías publicadas en la revista Life desde 1936 hasta 2000 (Grady, 2007). En ambos casos se obtienen unos magníficos conocimientos que no hubieran podido ser alcanzados sin la perspicaz utilización de sendos conjuntos de imágenes, y ambos casos constituyen un magnífico ejemplo de las grandes posibilidades que ofrece la incorporación de las imágenes a la investigación social.

\section{CONCLUSIÓN: SOCIOLOGÍA DE LO VISIBLE Y VISUALIZACIÓN DE LA SOCIOLOGÍA}

Piort Sztompka ha propuesto recientemente un cambio paradigmático para la sociología, una «tercera sociología» que vendría a sustituir tanto a la primera, centrada en el estudio de los sistemas y organismos sociales, como a la segunda, centrada en el estudio del comportamiento y de la acción individual de los agentes (Sztompka, 2008). Esta tercera sociología tendría por objeto el estudio de los fenómenos de la vida cotidiana. Se trataría, así, de estudiar la «existencia social» real y concreta, más acá de las abstracciones normalmente vinculadas al tratamiento de los fenómenos macro (sistemas y estructuras supuestamente existentes por encima de los individuos), y más allá de las abstracciones de los fenómenos micro (conductas y acciones fundadas en el interior de la vida de los individuos). «La idea de la existencia social -dice Sztompka- focaliza aquello que realmente ocurre en la sociedad humana, en un nivel que se ubica entre las estructuras y las acciones, allí donde las constricciones de las estructuras y de las dinámicas de las acciones producen eventos sociales reales, experimentados y observables» (Sztomp7ka, 2008:25). Desde esta perspectiva de sociología de la vida cotidiana, en el análisis del hecho o evento social se funden tanto los componentes de la agencia o personales, como los componentes contextuales o estructurales. Entre ambos polos se encuentran las únicas situaciones sociales reales y observables que caracterizan tanto la condición humana como la existencia social, por lo que con su tercera sociología Sztompka nos propone, también, un retorno metodológico a lo real-concreto, a todo aquello que técnicamente puede captarse con la observación directa, con el mirar de los ojos del cuerpo, y con sus principales extensiones técnicas, es decir, con la fotografía y con los medios de producción audiovisual.

EMPIRIA. Revista de Metodología de Ciencias Sociales. N. ${ }^{\circ}$ 22, julio-diciembre, 2011, pp. 113-140. ISSN: $1139-5737$ 
Para Sztompka, así como para Howard Becker (Becker, H. S., 2000), es fundamental que los científicos sociales no se dediquen en exclusiva a la mera interpretación de imágenes, sino que incorporen la producción audiovisual a sus procesos de investigación. Es obvio que mediante la aplicación del análisis de contenido a conjuntos de imágenes existentes pueden obtenerse importantes conocimientos sociales, pero también es obvio que la realización de fotografías, y su utilización como fuente primaria de datos, presenta otras muchas ventajas. Por ejemplo, se sustituye el mirar pasivo, en el que aparecen y desaparecen miles de estímulos visuales que no reciben ni siquiera la mínima atención, por el mirar intencional, mediante el que filtramos conscientemente las imágenes, otorgándoles su debida relevancia. La fotografía también nos enseña que debemos enfocar algo, seleccionando hechos importantes en el contexto de la situación bajo estudio; que debemos enmarcar la imagen, eliminando de la vista aquello que consideremos menos necesario o marginal; y que debemos determinar la profundidad de campo, distinguiendo el fondo de los primeros planos. Mediante el análisis del vasto universo iconográfico disponible, y mediante la producción de imágenes integradas en el proceso investigador, el científico-social podrá desvelar estructuras ocultas de la realidad social: interaccionales, normativas, ideales, de oportunidad y de distribución de la desigualdad (Sztompka, 2008:28). En suma, esta sociología de la vida cotidiana, de la existencia y de los hechos sociales vividos concreta y realmente, constituye también una sociología de lo visible, una sociología que pretende huir de lo meramente abstracto, orientándose hacia una elaboración teórica y conceptual basada en el rigor empírico implicado siempre en el pormenorizado análisis de las apariencias, de las representaciones y de los fenómenos visibles.

Tal y como paradigmáticamente nos muestra esta singular sociología de la vida cotidiana, el abanico de posibilidades que pudiera ofrecer una sociología que hiciera uso intensivo y extensivo de la visualidad implícita en las relaciones humanas, así como del aprovechamiento técnico que incorpora lo visual en tanto modo de representación, podría ser enormemente amplio. En este sentido, la orientación visual de la sociología debería desplegarse al menos en cuatro ámbitos fundamentales. Primero, en una sociología de la cultura visual que aplicara la perspectiva sociológica a la explicación y comprensión de todos los fenómenos visuales presentes en nuestro mundo, esto es, al amplísimo universo iconográfico en el que vivimos. Segundo, en una sociología visual y audiovisual que tratara de extraer conocimiento netamente sociológico analizando imágenes existentes en los universos iconográficos de nuestros mundos sociales. Tercero, en una fotosociología que utilizara la fotografía, y también otros medios técnicos disponibles, como instrumento de producción de datos visuales primarios enmarcados en diversas estrategias y procesos de investigación social. Finalmente, en una sociología de la visualidad que considerase, no sólo las imágenes o visualizaciones materiales (ya sea para explicarlas; para extraer de ellas conocimiento social; o para producir con ellas datos primarios), sino todo el orden perceptivo implícito en el mirar de la observación directa, esto es, en el hecho de

EMPIRIA. Revista de Metodología de Ciencias Sociales. N. . 22, julio-diciembre, 2011, pp. 113-140. ISSN: $1139-5737$ 
que los seres humanos tienen ojos tanto en el cuerpo como en el alma y que, por tanto, continuamente se figuran y visualizan la realidad, bien mediante imágenes materiales, bien mediante imágenes mentales.

Para Mitchell el contenido de la cultura visual se despliega sobre tres diferentes procesos: el proceso de ver el mundo; el proceso de hacer representaciones visuales del mundo; y el proceso de imaginar o de crear imágenes mentales del mundo (Mitchell, 2005:239). Es decir, miramos, visualizamos e imaginamos el mundo, y estas tres formas de visualidad deben necesariamente ser investigadas por las ciencias sociales. Además, este triple contenido de la cultura visual se corresponde con los tres modos en los que las imágenes pueden ser incorporadas a los procesos de descubrimiento científico. En primer lugar, la observación visual directa constituye un mecanismo esencial en la obtención de conocimiento. Así lo puso de manifiesto Erving Goffman en sus estudios sobre la representación de la persona en la vida cotidiana (Goffman, 2009). La ciencia, en segundo lugar, produce un sinnúmero de visualizaciones de todo tipo conectadas, en tanto índex, a un conjunto de datos extraídos de la realidad. En tercer lugar, las «imágenes mentales» juegan siempre un papel esencial tanto en el descubrimiento científico como en la comprensión científica del mundo. Sin imaginación, que en gran parte es visual, la ciencia detendría tarde o temprano su desarrollo.

La cantidad, diversidad y relevancia de las aplicaciones científicas que pueden tener las imágenes para la sociología, nos lleva a defender, no tanto la necesidad de una sociología visual, subdisciplina sobre la que recaería en exclusiva la responsabilidad de incorporar las imágenes a la ciencia social, sino también, y fundamentalmente, una visualización de la sociología, esto es, una general incorporación de las imágenes, y de todos los procesos implícitos en la visualización de la realidad, a los procesos de producción de conocimiento que normalmente establezca la sociología. La sociología visual puede ser necesaria, bien con una función transitoria en tanto catalizadora o ariete de la incorporación visual general, bien de forma permanente en cuanto subdisciplina auxiliar especializada en prestar apoyo a la sociología general. Sin embargo, sería absurdo considerar y mantener sine die como subdisciplina lo que constituye esencial y epistemológicamente uno de los tres fundamentales modos de representación del mundo. En este sentido, sería substantivamente tan absurdo hablar de una sociología de las imágenes, como hablar de una sociología de los números, o de una sociología de las palabras.

De ahí que elevar la competencia científico-visual de los sociólogos, entendida como las capacidades y actitudes necesarias para lograr un eficiente pensamiento y actuación visual a lo largo de todo el proceso de investigación (Pauwels, 2000:7), constituya una tarea prioritaria y urgente. En este sentido, para Pauwels el problema clave estriba en saber cómo asegurar un uso apropiado y transparente de las propiedades y de los medios visuales en el discurso científico, lo que constituye otra forma de subrayar lo señalado por Becker, esto es, que el problema central estriba en saber cómo usar las fotografías y las películas para

EMPIRIA. Revista de Metodología de Ciencias Sociales. N. ${ }^{\circ} 22$, julio-diciembre, 2011, pp. 113-140. ISSN: $1139-5737$ 
elaborar un argumento y cómo desplegarlas en tanto evidencias del argumento que se haya construido (Becker, 2004). La resolución de este problema central se configura, en sí mismo, como un importante reto de conocimiento todavía no satisfactoriamente resuelto.

Con la finalidad de desarrollar una sociología más competente en términos visuales, Luc Pauwels nos ofrece algunas importantes recomendaciones, de entre las que destacaremos cuatro. Primero, que una ciencia social más orientada hacia la visualidad debe potenciar tres ámbitos: el saber mirar y ver mediante observación directa; el saber mirar y ver el universo completo de representaciones visuales; y el saber producir materiales visuales como parte esencial del discurso científico. Segundo, que se debe asumir y aprovechar científicamente la doble naturaleza de la fotografía, su naturaleza mimética, mediante la que pretende ser un reflejo de la realidad representada, y su naturaleza expresiva y estética, que alude a la gran importancia que adquieren los aspectos formales de cualquier representación, necesarios y presentes en todo tipo de discurso científico. Tercero, que resulta necesario trabajar en pos de una metodología y una teoría visual mucho más explícita, ya que apenas se han esbozado las maneras de obtener datos de investigación, o los modos en los que puedan hacerse legítimas proposiciones visualmente informadas. Y, cuarto, que también será necesario realizar un gran esfuerzo en la formación visual tanto de los científicos sociales como de los consumidores de ciencia social, pues sin un lenguaje común la comunicación y validación tanto de los procesos como de los resultados sería imposible (Pauwels, 2000).

Ahora bien, el desarrollo de la competencia visual de los sociólogos, condición sine qua non para el desarrollo de una general visualización de la sociología, esto es, para una incorporación del modo de representación icónico al quehacer normal de la sociología, no se puede llevar a cabo sin el estímulo de una doble conciencia: la conciencia de la necesidad que la sociología tiene de incorporar imágenes a sus procesos de producción de conocimiento, así como la conciencia de la dificultad epistemológica, metodológica y técnica que tal proceso comporta.

En cualquier caso, seguir ciegos frente a la realidad substancial e instrumental de las imágenes implicaría también renunciar al proyecto de una ciencia social multimodal en la que se integren nuevas perspectivas ontológicas, epistemológicas, metodológicas y técnicas. La sociología, ciencia que estudia las causas, la naturaleza y las consecuencias de la interactividad y de la intercomunicación humana, podría encontrar en este futuro científico multimodal el estímulo que necesita para su pleno desarrollo. La especialización modal exclusivista constituye hoy, tanto en términos de representación como de comunicación científica, un empobrecimiento que no hace sino cercenar el desarrollo de la enorme potencialidad y oportunidades futuras que se le presentan a la sociología. Creemos que la ciencia social debe considerar muy seriamente el continuo epistemológico que parte del mirar, transita por el narrar y llega hasta al computar. Esto es, modelos icónicos, lingüísticos y matemáticos; imágenes, palabras y números; cuadros, historias y fórmulas.

EMPIRIA. Revista de Metodología de Ciencias Sociales. N. . 22, julio-diciembre, 2011, pp. 113-140. ISSN: $1139-5737$ 


\section{BIBLIOGRAFÍA}

BARTHes, R. (1989): La cámara lúcida. Nota sobre la fotografía, Barcelona, Paidós.

Becker, H. S. (1974): «Photography and Sociology», en Studies in the Anthropology of Visual Communication, 1, pp. 3-26.

BeCKer, H. S. (2000): «What Should Sociology Look Like in the (Near) Future?», en Contemporary Sociology, 29, 2, pp. 333-36.

BECKER, H. S. (2004): «Afterword: photography as evidence, photography as exposition», en C. Knowles \& P. SweETMan (eds.) Picturing the Social Landscape: Visual Methods and the Sociological Imagination, Routledge, London, pp. 193-197.

Berger, J. (2000): Modos de ver, Barcelona, Gustavo Gili.

Berger, J. (2001): Mirar, Barcelona, Gustavo Gili.

Berger, J. y Mohr, J. (2008): Otra manera de contar, Barcelona, Gustavo Gili.

BericAt Alastuey, E. (2010): «Ciencias sociales y cultura audiovisual: el conocimiento de la fotografía», en J. A. Roche Cárcel, La sociología como una de las Bellas Artes. La influencia de la literatura y de las artes en el pensamiento sociológico, Barcelona, Anthropos.

BigGs, M. A. R. (2004): «Visualization and Wittgenstein's 'Tractatus' », en G. Malcolm (ed.), Multidisciplinarity approaches to visual representation and interpretations, Londres, Elsevier, pp. 293-303.

De Miguel, J. M. DE y PINTo, C. (2002): Sociología visual, Madrid, CIS.

De Regt, H. W. (1999): «Ludwig Boltzmann's Bildtheorie and Scientific Understanding», en Synthese, no 119, pp. 113-134.

DikOvitskaya, M. (2005): Visual culture: the Study of the Visual after the cultural Turn, Cambridge, The MIT Press.

DuBoIs, Ph. (1986): El acto fotográfico. De la representación a la recepción, Barcelona, Paidós.

Goffman, E. (1979): Gender Advertisements, Nueva York, Harper \& Row.

GofFMAn, E. (2009): La presentación de la persona en la vida cotidiana, Buenos Aires, Amorrortu.

GoldsteIn, B. M. (2007): «All Photos Lie: Images as Data», en G. C. Stanczak (ed.), Visual Research Methods. Image, Society, and Representation, Londres, Sage, pp. 61-82.

GraDY, J. (2007): «Advertising images as social indicators: depictions of blacks in LIFE magazine, 1936-2000», en Visual Studies, vol. 22, n 3, pp. 213-39.

HANSEN, Ch. D. y Johnson, Ch. R. (ed.) (2005): Visualization Handbook, Oxford, Elsevier Butterworth-Heinemann.

Howells, R. (2003): Visual Culture, Cambridge, Polity Press.

KRESS, G. y LEEUwEN, Th. Van (1996): Reading Images: The Grammar of Visual Design, Nueva York, Routledge.

KRESS, G. y Leeuwen, Th. Van (2001): Multimodal discourse. The modes and media of contemporary communication, London, Hodder.

Lynch, M. (1991): «Pictures of Nothing? Visuals Construals in Social Theory», en Sociological Theory, Vol. 9, $\mathrm{n}^{\mathrm{o}}$ 1, pp. 1-21.

Mitchell, W. J. T. (2005): «An Interview with W. J. T. Mitchell», en M. Dikovitskaya, Visual culture: the Study of the Visual after the cultural Turn, Cambridge, The MIT Press, pp. 238-257.

EMPIRIA. Revista de Metodología de Ciencias Sociales. N. ${ }^{\circ}$ 22, julio-diciembre, 2011, pp. 113-140. ISSN: $1139-5737$ 
Mirzoeff, N. (1998): «The subject of visual culture», en N. Mirzoeff (ed.) The Visual Culture Reader, Londres, Routledge, pp. 3-23.

MÜLLER, M. G. (2008): «Visual Competence: a new paradigm for studying visuals in the social sciences?», en Visual Studies, Vol. 23, no 2, pp. 101-112.

PAUWELS, L. (2000): «Taking the visual turn in research and scholarly communication key issues in developing a more visual literate (social) science», en Visual studies, Vol 15, no 1 , pp. 7-14.

PeIrCE, C. S. (1931-1935): Collected Papers of Charles. Sanders Peirce, vols. 1-6, Charles Hartshorne \& Paul Weiss (eds.), Cambridge, MA, Harvard University Press.

ReEDER, H. P. (1980): «Husserl and Wittgenstein on the "Mental Picture Theory of Meaning"», en Human Studies, $\mathrm{n}^{\circ}$ 3, pp. 157-167.

SAmuels, J. (2007): «When Words Are Not Enough: Eliciting Children's Experiences of Buddhist Monastic Life», en G. C. Stanczak (ed.), Visual Research Methods. Image, Society, and Representation, Londres, Sage, pp. 197-224.

Schroeder, W. J. y Martin, K. M. (2005): «Overwiew of Visualization», en Ch. D. HANSEN y CH. R. JoHnson, Visualization Handbook, Oxford, Elsevier ButterworthHeinemann, pp. 3-38.

StAncZaK, G. C. (ed.) (2007): Visual Research Methods. Image, Society, and Representation, Londres, Sage.

SzTompKa, P. (2008): «The Focus of Every Life: a New Turn in Sociology», en European Review, Vol. 16, $\mathrm{N}^{\circ} 1$, pp. 23-27.

SzTOMPKA, P. (2005): Socjologia wizualna: fotografia jako metoda badawcza (Visual Sociology:Photography as a Research Method), Varsovia, PWN Publishers.

Wagner, J. (2007): «Observing Culture and Social Life: Documentary Photography, Fieldwork, and Social Research», en G. C. Stanczak (ed.), Visual Research Methods. Image, Society, and Representation, Londres, Sage, pp. 23-59.

VISSER, H. (1999): «Boltzmann and Wittgenstein or How Pictures became Linguistic», in Synthese, $\mathrm{N}^{\mathrm{o}} 119$, pp. 135-156.

WitTGenstein, Ludwig (2000): Tractatus Logico-Philosophicus, Madrid, Alianza.

Zeman, J. (1977): «Peirce's Theory of Signs», en T. Sebeok (ed.) Perfusion of Signs, Bloomington, IN, Indiana University Press, pp. 22-39. 